\title{
Glucocorticoid Regulation of Insulin Receptor and Substrate IRS-1 Tyrosine Phosphorylation in Rat Skeletal Muscle In Vivo
}

\author{
Francesco Giorgino, Abdulraof Almahfouz, Laurie J. Goodyear, and Robert J. Smith \\ Research Division, Joslin Diabetes Center, and Department of Medicine, Brigham and Women's Hospital, Harvard Medical School, \\ Boston, Massachusetts 02215
}

\section{Abstract}

To test the hypothesis that glucocorticoid-induced insulin resistance might originate from abnormalities in insulin receptor signaling, we investigated the effects of glucocorticoids on in vivo tyrosine phosphorylation of the insulin receptor and the insulin receptor substrate IRS-1 in rat skeletal muscle. Male Sprague-Dawley rats were treated with cortisone $(100 \mathrm{mg} / \mathrm{kg}$ for $5 \mathrm{~d}$ ) and compared to pair-fed controls. Cortisone treatment of rats resulted in both hyperglycemia and hyperinsulinemia. Anesthetized animals were injected with $10 \mathrm{U} / \mathrm{kg}$ insulin via cardiac puncture and, after $2 \mathrm{~min}$, hindlimb muscles were removed, snap-frozen, and homogenized in SDS. Protein tyrosine phosphorylation was studied by immunoblotting with phosphotyrosine antibody. Insulin receptors and substrate IRS-1 were identified and quantified with specific antibodies. Cortisone treatment increased the amount of insulin receptor protein by $36 \%$, but decreased the total level of receptor tyrosine phosphorylation ( $69 \pm 4 \%$ of control, $P<0.05$ ). The decreased level of receptor phosphorylation was explained by a reduced number of receptors containing phosphorylated tyrosine residues (64.6 $\pm 5 \%$ of control, $P<0.05)$. Glucocorticoid excess decreased skeletal muscle IRS-1 content by $50 \%$, but did not significantly alter the total level of IRS-1 tyrosine phosphorylation. The apparent $M_{\mathrm{r}}$ of IRS-1 was reduced by $\sim 10 \mathrm{kD}$. Treatment with protein phosphatase-2A reduced IRS-1 $M_{\mathrm{r}}$ in control but not in glucocorticoid-treated muscle indicating that the lower $M_{\mathrm{r}}$ likely results from lower phosphoserine and/or phosphothreonine content. To investigate the role of hyperinsulinemia in the glucocorticoid response, rats were made insulin-deficient with streptozotocin $(100 \mathrm{mg} / \mathrm{kg}$, i.p.). Subsequent treatment with cortisone for $5 \mathrm{~d}$ had no effects on insulin levels, tyrosine phosphorylation of insulin receptors or IRS-1, or the $M_{r}$ of IRS-1. In conclusion, glucocorticoid-treated skeletal muscle is characterized by: $(a)$ decreased total tyrosine phosphorylation of insulin receptors as a result of a reduction in the pool of receptors undergoing tyrosine phosphorylation; (b) decreased IRS-1 content and reduced serine and/or threonine phosphorylation of IRS-1. Glucocorticoid-induced hyperinsulinemia appears to be essential for the development of these alterations. (J. Clin. Invest. 1993. 91:2020-2030.) Key words: autophosphorylation • cortisone • insulin receptor substrate-1 • insulin resistance $\bullet$ tyrosine kinase activity

Address reprint requests to Dr. Robert J. Smith, Research Division, Joslin Diabetes Center, 1 Joslin Place, Boston, MA 02215.

Received for publication 31 July 1992 and in revised form 21 December 1992.

J. Clin. Invest.

(C) The American Society for Clinical Investigation, Inc.

$0021-9738 / 93 / 05 / 2020 / 11 \$ 2.00$

Volume 91, May 1993, 2020-2030

\section{Introduction}

An excess of glucocorticoid hormones, commonly observed in patients treated with these steroids or affected by Cushing's syndrome, leads to insulin resistance $(1,2)$. In humans and in several experimental models, glucocorticoid excess has been shown to antagonize insulin action by inhibiting insulin-mediated glucose uptake and utilization by insulin-sensitive tissues $(3,4)$. In skeletal muscle, the major site of insulin-mediated glucose disposal, glucocorticoid treatment results in a decreased ability of insulin to maximally stimulate glucose transport $(5,6)$. Although glucocorticoid-induced insulin resistance has been recognized for over three decades, the molecular basis for the defect in insulin action has not yet been identified.

According to the current model of insulin transmembrane signaling, insulin binding to a specific tetrameric receptor located at the cell surface $(7)$ results in receptor autophosphorylation and activates the tyrosine kinase intrinsic to the receptor's $\beta$ subunit ( $8-10$ ). This leads in turn to tyrosine phosphorylation of intracellular substrate proteins (11-16) that may function as messengers for various biological effects of insulin. The most ubiquitous substrate for the insulin receptor kinase is a cytoplasmic phosphoprotein with $M_{\mathrm{r}}$ between 160,000 and 185,000 . Tyrosine phosphorylation of this protein in response to insulin stimulation is evident in the major insulin-sensitive tissues, including liver, skeletal muscle, and fat cells (17-19). Recently, a cDNA encoding a component of the $M_{\mathrm{r}} 160,000$ 185,000 protein was sequenced, and the corresponding protein was named "IRS-1" (insulin receptor substrate-1)1 $(18,20)$. The expression and tyrosine phosphorylation of IRS-1 represent specific molecular events to investigate in the search for abnormalities in the insulin signaling pathway that may lead to insulin resistance.

The observed effects of glucocorticoids on insulin receptor content and binding activity have varied, depending on the specific glucocorticoid used, the cell type studied, and the employment of in vivo or in vitro experimental conditions (reviewed in reference 2 ). A lack of correlation between changes in insulin binding activity and impairment in insulin action has lead to the conclusion that a postbinding mechanism is responsible for glucocorticoid-induced insulin resistance (2123 ). When insulin receptor tyrosine kinase activity was measured in the skeletal muscle and adipocytes of hypercortisolemic animals, no decrease in either receptor or substrate phos-

1. Abbreviations used in this paper: $\mathrm{CHO}$, Chinese hamster ovary; IR, insulin receptor; $\mathbf{I R}_{\mathbf{F 1 1 4 6}}$, insulin receptor with phenylalanine substituted for tyrosine 1146; $\alpha$-IRCt, anti-insulin receptor antibody; IRS-1, insulin receptor substrate-1; $\alpha$-IRS-1, anti-IRS-1 antibody; KLH, keyhole limpet hemocyanin; PP-2AC, protein phosphatase-2AC; pp95, tyrosine phosphoprotein with $M_{\mathrm{r}}$ of 95,000 ; pp 170, tyrosine phosphoprotein with $M_{\mathrm{r}}$ of 170,$000 ; \alpha$-PY, anti-phosphotyrosine antibody; STZ, streptozotocin. 
phorylation was found $(24,25)$. However, these prior studies evaluated insulin receptor autophosphorylation in vitro using detergent-extracted and partially purified receptors (24), and tyrosine kinase activity was measured with exogenous or synthetic substrates $(24,25)$. The effects of glucocorticoids on tyrosine phosphorylation have not been studied in vivo, and specific cellular proteins that are substrates for the insulin receptor kinase have not been investigated.

To study protein tyrosine phosphorylation in vivo, we have recently used a method (26) that involves insulin injection in intact animals, followed by rapid isolation of muscle tissue and identification of tyrosine phosphoproteins with specific antibodies. This experimental procedure makes it possible to assess the phosphorylation reactions that occur in the intact animal in response to circulating insulin and to study endogenous substrate proteins. When in vivo protein tyrosine phosphorylation was studied in streptozotocin-induced diabetic rats (26), a paradoxical increase in tyrosine phosphorylation of both the insulin receptor and substrate IRS-1 was found, in marked contrast with other studies where tyrosine phosphorylation was evaluated in vitro (27-29). With the assumption that this in vivo approach could reveal defects in insulin signaling that are not evident with in vitro techniques, we have investigated the effects of glucocorticoids on insulin-stimulated tyrosine phosphorylation in rat skeletal muscle. Our results indicate that glucocorticoid excess results in decreased insulin receptor tyrosine phosphorylation and changes in both the expression and the molecular structure of the substrate IRS-1.

\section{Methods}

\section{Materials}

Human insulin (Humulin R) was purchased from Eli Lilly \& Co. (Indianapolis, IN). Cortisone acetate (Cortone) was from Merck Sharp \& Dohme (West Point, PA). Streptozotocin (STZ), aprotinin, PMSF, DTT, and $\beta$-mercaptoethanol were from Sigma Chemical Co. (St. Louis, MO). Sodium orthovanadate, ethylmorpholine, and ethanolamine hydrochloride were from Aldrich Chemical Co., Inc. (Milwaukee, WI). Keyhole limpet hemocyanin (KLH) was from CalbiochemBehring Corp. (La Jolla, CA ). Freund's adjuvant was from Difco Laboratories (Detroit, MI). Protein A-Sepharose was from Pierce Chemical Co. (Rockford, IL). Affigel 15 and reagents for SDS-PAGE were purchased from Bio-Rad Laboratories (Richmond, CA ). ${ }^{125}$ I-labeled protein A was from ICN Biomedical (Costa Mesa, CA). [ $\left.\gamma-{ }^{32} \mathrm{P}\right]$ ATP was from New England Nuclear (Boston, MA). The synthetic peptide, ArgThr-Tyr-Asp-Glu-His-Ile-Pro-Tyr-Thr-His, which contains the amino acid sequence between residues 1328 and 1338 of the $\beta$ subunit of the rat insulin receptor (30), was purchased from Dr. David Coy (Tulane University, New Orleans, LA).

\section{Animals}

Male Sprague-Dawley rats weighing $\sim 200 \mathrm{~g}$ were purchased from Taconic Farms (Germantown, NY). To induce a state of glucocorticoid excess, rats were injected daily at 10:00 a.m. with cortisone acetate ( 100 $\mathrm{mg} / \mathrm{kg}$ body wt, s.c.) for $5 \mathrm{~d}$. This protocol results in plasma glucocorticoid concentrations similar to those that occur in rats during a major stress state (31). Glucocorticoid-treated animals were allowed free access to standard rat laboratory diet plus water. Because glucocorticoid treatment resulted in reduced food intake $(\sim 60 \%$ of control $)$, treated animals were compared with pair-fed controls. The pair-fed group received an amount of food equal to the previous day's consumption in the glucocorticoid-treated group. For selected studies, rats were made diabetic and insulin-deficient by i.p. injection of STZ in citrate buffer, $\mathrm{pH} 4.5(100 \mathrm{mg} / \mathrm{kg}$ body $\mathrm{wt})$. Blood glucose was determined $3 \mathrm{~d}$ later and animals were considered diabetic only if values were in excess of $300 \mathrm{mg} \%$. Blood glucose levels were determined with an AccuCheck meter (Boehringer Mannheim Corp., Indianapolis, IN) on tail vein blood samples. This method has been shown to correlate with laboratory glucose measurements (32). Circulating insulin levels were measured as described by Soeldner and Sloane (33) using rat insulin standard. Quantitation of muscle DNA was performed using the fluorimetric method described by Labarca and Paigen (34).

\section{Procedures}

Preparation and purification of antibodies. Anti-phosphotyrosine antibody ( $\alpha$-PY) was prepared in rabbits by injection of phosphotyrosine polymerized by 1-ethyl-3(3-dimethyl-aminopropyl)carbodiimide with alanine, threonine, and KLH as previously described (26). Nonimmunoglobulin proteins were extracted with $6 \%$ octanoic acid precipitation. Then, $\alpha$-PY was purified by affinity chromatography on a phosphotyramine-Sepharose column, as previously described (35). The final protein concentration of the antibody was $200-500 \mu \mathrm{g} / \mathrm{ml}$.

An anti-insulin receptor antibody $(\alpha-$ IRCt $)$ against the synthetic peptide, Arg-Thr-Tyr-Asp-Glu-His-Ile-Pro-Tyr-Thr-His, which contains the carboxy-terminal amino acid sequence between residues $1328-1338$ of the $\beta$ subunit of the cloned rat insulin receptor (30), was generated and purified by affinity chromatography on a peptide-coupled Affigel 15 column as previously described $(26,35)$. The final protein concentration was $200 \mu \mathrm{g} / \mathrm{ml}$.

Multiple antibodies to the cloned rat IRS-1 (20) were made available to us and utilized in these studies. An affinity-purified antipeptide antibody specific to the last 14 amino acids in the carboxy-terminal region of IRS-1 was provided by Dr. G. E. Lienhard (Hanover, NH). Antibodies specific to the whole protein produced in a baculovirus system and the first 12 amino acids of IRS-1 were provided by Drs. C. R. Kahn and M. F. White (Boston, MA). All of these antibodies proved to effectively react with IRS-1 in rat skeletal muscle.

Preparation of samples for immunoprecipitation. Animals were studied between 9:30 and 11:00 a.m. Rats were anesthetized by the administration of sodium amobarbital ( $150 \mathrm{mg} / \mathrm{kg}$ body wt, i.p.) 10 15 min before the experiment. Insulin (Humulin R) was injected via transthoracic cardiac puncture, and after 2 min hindlimb skeletal muscles were quickly removed and frozen in liquid $\mathrm{N}_{2}$. Muscle proteins were extracted as previously described (26), with minor modifications. Briefly, the frozen muscle (2-3 g) was powdered with a stainless steel mortar and pestle and homogenized with a Polytron PTA 20S generator (Brinkmann Instruments, Inc., Westbury, NY) for $45 \mathrm{~s}$ in homogenization buffer ( $50 \mathrm{mM}$ Hepes, $\mathrm{pH} 7.5,150 \mathrm{mM} \mathrm{NaCl}, 1 \%$ SDS, 50 mM DTT, and 2 mM EDTA). A constant ratio (1:5, wt/ vol) of muscle tissue to homogenization buffer was used for all specimens. The sample was heated at $100^{\circ} \mathrm{C}$ in a water bath during homogenization and subsequently stirred at $100^{\circ} \mathrm{C}$ for an additional $4 \mathrm{~min}$. After centrifugation at $200,000 \mathrm{~g}$ for $1 \mathrm{~h}$, protein and nucleic acids were precipitated by the addition of $10 \%$ (final concn) TCA to the supernatant at $4^{\circ} \mathrm{C}$. The TCA-precipitated material was washed once with $10 \% \mathrm{TCA}$, then twice with ethyl ether/ethanol $(1: 1, \mathrm{vol} / \mathrm{vol})$ in order to extract the TCA, and finally lyophilized. The final yield of dry precipitate was about $0.06-0.07 \mathrm{~g} / \mathrm{g}$ of muscle and was not different for samples from glucocorticoid-treated animals compared to controls.

Immunoprecipitation and immunoblotting. Equivalent amounts (100 mg) of lyophilized protein were dissolved in $4 \mathrm{ml} 0.1 \mathrm{~N} \mathrm{NaOH}$,

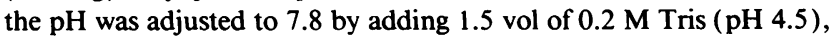
and protease and phosphatase inhibitors were added (1 mM EDTA, 1 $\mathrm{mM}$ PMSF, $10 \mu \mathrm{g} / \mathrm{ml}$ aprotinin, $1 \mathrm{mM}$ sodium orthovanadate, and $0.01 \%$ sodium azide). The solution was cleared by centrifugation at $200,000 \mathrm{~g}$ for $1.5 \mathrm{~h}$. Protein concentrations were determined with the Bradford dye binding assay (36) using dye reagent and immunoglobulin protein standards from Bio-Rad Laboratories. The solution was adjusted to $8 \mathrm{mg} / \mathrm{ml}$ with Tris buffer and $10 \mathrm{ml}$ of solution were used for immunoprecipitation.

To identify and quantify tyrosine phosphoproteins, affinity-purified $\alpha$-PY antibody was added to a final concentration of $2 \mu \mathrm{g} / \mathrm{ml}$, and 
the samples were incubated at $4^{\circ} \mathrm{C}$ overnight. $\alpha$-PY antibody was then adsorbed with protein A-agarose beads for $2 \mathrm{~h}$ at $4^{\circ} \mathrm{C}$. The resulting immunocomplexes were washed twice by resuspension and brief centrifugation in $1 \mathrm{ml}$ of $50 \mathrm{mM}$ Hepes buffer ( $\mathrm{pH} \mathrm{7.6)}$ containing $1 \%$ Triton X-100, $0.1 \%$ SDS, $100 \mathrm{mM}$ sodium fluoride, and $1 \mathrm{mM}$ sodium orthovanadate. The immunoprecipitated tyrosine phosphoproteins were then boiled in Laemmli buffer with $100 \mathrm{mM}$ DTT for $4 \mathrm{~min}$ and separated on $7 \%$ polyacrylamide gels by electrophoresis.

Proteins resolved by SDS-PAGE were transferred onto nitrocellulose sheets (Schleicher \& Schuell, Inc., Keene, NH) in transfer buffer containing $10 \mathrm{mM}$ Tris, $192 \mathrm{mM}$ glycine, $20 \% \mathrm{vol} / \mathrm{vol}$ methanol, and $0.02 \% \mathrm{SDS}$ at $80 \mathrm{~V}$ for $2.5 \mathrm{~h}$. To reduce nonspecific antibody binding, the sheets were soaked in 5\% BSA in rinse buffer containing $10 \mathrm{mM}$ Tris ( $\mathrm{pH} 7.8$ ), $0.9 \% \mathrm{NaCl}$ and $0.01 \%$ sodium azide for $2 \mathrm{~h}$ at $37^{\circ} \mathrm{C}$. The sheets were then incubated with $2 \mu \mathrm{g} / \mathrm{ml} \alpha$-PY in rinse buffer containing $5 \% \mathrm{BSA}$ for $10-16 \mathrm{~h}$ at $4^{\circ} \mathrm{C}$. After washing twice with rinse buffer plus $0.05 \%$ Nonidet $P 40$, and once with rinse buffer plus $0.1 \%$ Tween20 , the sheets were incubated with ${ }^{125} \mathrm{I}$-protein $\mathrm{A}(1 \mu \mathrm{Ci} / \mathrm{ml})$ for $1 \mathrm{~h}$ at $25^{\circ} \mathrm{C}$, washed again with rinse buffer as described above, air-dried, and subjected to autoradiography with X-Omat (Eastman Kodak Co., Rochester, NY) film in the presence of an intensifying screen at $-80^{\circ} \mathrm{C}$ for 6-48 h. Titers of muscle proteins immunoprecipitated and then blotted with $\alpha$-PY showed a linear relationship between the amount of starting protein and the density of the autoradiographic images. Moreover, in control experiments, the $\alpha$-PY antibody was found to immunoprecipitate $90 \%$ and $80 \%$ of tyrosine phosphorylated insulin receptors and IRS-1, respectively. This was assessed by comparing the amount of tyrosine phosphorylated insulin receptors and IRS-1 (measured by immunoblotting an aliquot of the muscle protein extracts with $\alpha-\mathrm{PY}$ antibody) before and after immunoprecipitation with $\alpha$-PY antibody.

To specifically identify and quantify insulin receptors and substrate IRS-1 in muscle protein extracts, parallel experiments were performed using an anti-insulin receptor antibody, $\alpha$-IRCt, as previously described (26), or one of several anti-IRS-1 antibodies, $\alpha$-IRS-1. A linear relationship between the amount of muscle protein and the density of autoradiographic images was observed for samples immunoprecipitated and then blotted with $\alpha$-IRCt and $\alpha$-IRS-1, similar to $\alpha$-PY. Autoradiographic images were quantified by densitometry, and data were expressed using arbitrary units after normalizing to control values within each gel.

Table I. General Characteristics of the Experimental Animals

\begin{tabular}{|c|c|c|c|c|}
\hline \multirow[b]{2}{*}{ Rats } & \multicolumn{2}{|c|}{ Body wt } & \multirow[b]{2}{*}{ Blood glucose } & \multirow[b]{2}{*}{ Plasma insulin } \\
\hline & Initial & Final & & \\
\hline & \multicolumn{2}{|c|}{$g$} & $m g \%$ & $\mu U / m l$ \\
\hline \multicolumn{5}{|l|}{ Group a } \\
\hline G Tx & $223 \pm 2$ & $197 \pm 2 *$ & $248 \pm 16^{\ddagger}$ & $165 \pm 16^{\ddagger}$ \\
\hline Pair-fed C & $222 \pm 1$ & $230 \pm 2^{*}$ & $79 \pm 1$ & $15 \pm 2$ \\
\hline \multicolumn{5}{|l|}{ Group b } \\
\hline $\mathrm{STZ}+\mathrm{G} \mathrm{Tx}$ & $230 \pm 2$ & $174 \pm 6^{*}$ & $388 \pm 21^{8}$ & $11 \pm 3^{8}$ \\
\hline Pair-fed STZ & $235 \pm 2$ & $215 \pm 4^{*}$ & $391 \pm 27^{\S}$ & $25 \pm 13^{\S}$ \\
\hline Normal controls & $225 \pm 1$ & $264 \pm 5^{*}$ & $88 \pm 2$ & $75 \pm 10$ \\
\hline
\end{tabular}

Group a. Rats were treated with cortisone acetate for $5 \mathrm{~d}(\mathrm{G} \mathrm{Tx})$ and compared to pair-fed control rats (Pair-fed C).

Group b. Rats were injected with streptozotocin (see Methods) and subsequently treated with cortisone for $5 \mathrm{~d}(\mathrm{STZ}+\mathrm{G} \mathrm{Tx})$. Pair-fed streptozotocin-injected rats (Pair-fed STZ) were used as controls. Data on ad lib. fed normal control rats are also presented.

Blood glucose and plasma insulin concentrations were measured in the nonfasted state at the time animals were killed.

${ }^{*} P<0.05$ vs. initial body weight; ${ }^{\ddagger} P<0.05$ vs. pair-fed $C ;{ }^{\S} P<$ 0.05 vs. normal controls.
Preparation of in vitro phosphorylated insulin receptors. Chinese hamster ovary ( $\mathrm{CHO}$ ) cells expressing the wild-type insulin receptor $(\mathrm{CHO} / \mathrm{IR}$ cells) and the insulin receptor in which tyrosine-1146 has been replaced with phenylalanine $\left(\mathrm{CHO} / \mathrm{IR}_{\mathrm{F1146}}\right.$ cells) (37) were grown in F-12 medium containing $10 \%$ fetal bovine serum. Confluent monolayers of $\mathrm{CHO} / \mathrm{IR}$ and $\mathrm{CHO} / \mathrm{IR}_{\mathrm{F} 146}$ cells were harvested with ice-cold phosphate-buffered saline containing $0.2 \%$ EDTA and $1 \mathrm{mM}$ PMSF. Cells were solubilized in $50 \mathrm{mM}$ Hepes buffer ( $\mathrm{pH} 7.6)$ containing $120 \mathrm{mM} \mathrm{NaCl}, 2 \mathrm{mM}$ EDTA, $1 \mathrm{mM}$ PMSF, $10 \mu \mathrm{g} / \mathrm{ml}$ aprotinin, 1 $\mathrm{mM}$ sodium orthovanadate, and $1 \%$ Triton X-100 for 60 min at $4{ }^{\circ} \mathrm{C}$ with continuous shaking. The solubilized material was then centrifuged at $100,000 \mathrm{~g}$ for $60 \mathrm{~min}$, and the supernatant applied to a 4-ml wheat germ agglutinin agarose column preequilibrated with column buffer containing $50 \mathrm{mM}$ Hepes ( $\mathrm{pH} 7.6$ ), $150 \mathrm{mM} \mathrm{NaCl}, 1 \mathrm{mM}$ PMSF, and $0.1 \%$ Triton X-100. Glycoproteins were eluted with the same buffer containing $0.4 \mathrm{M} \mathrm{N}$-acetyl-D-glucosamine. Insulin receptors were incubated at $23^{\circ} \mathrm{C}$ for $60 \mathrm{~min}$ in $50 \mathrm{mM}$ Hepes buffer ( $\mathrm{pH}$ 7.6) containing $10 \mathrm{mM} \mathrm{MgCl}, 5 \mathrm{mM} \mathrm{MnCl}$, and $100 \mathrm{nM}$ insulin. Autophosphorylation was initiated by the addition of $10 \mu \mathrm{M}[\gamma$ ${ }^{32} \mathrm{P}$ ]ATP $(3 \mu \mathrm{Ci} / \mathrm{nmol})$. After $30 \mathrm{~min}$, the reaction was terminated by the addition of $50 \mathrm{mM}$ Hepes buffer ( $\mathrm{pH} 7.6$ ) containing $10 \mathrm{mM}$ ATP, $5 \mathrm{mM}$ EDTA, $10 \mathrm{mM}$ sodium pyrophosphate, $100 \mathrm{mM}$ sodium fluoride, $1 \mathrm{mM}$ sodium orthovanadate, $1 \mathrm{mM} \mathrm{PMSF}$, and $30 \mu \mathrm{g} / \mathrm{ml}$ leupeptin. ${ }^{32} \mathrm{P}$-labeled insulin receptors from either $\mathrm{CHO} / \mathrm{IR}$ or $\mathrm{CHO} /$ $\mathrm{IR}_{\mathrm{F} 1146}$ cells were then mixed with muscle protein extracts from the experimental animals and subjected to immunoprecipitation with $\alpha$ PY antibody added to a final concentration of $2 \mu \mathrm{g} / \mathrm{ml}$ as described above. Immunoprecipitated ${ }^{32} \mathrm{P}$-labeled receptors were quantified after SDS-PAGE by autoradiography.

Dephosphorylation experiments. The serine- and threonine-specific protein phosphatase-2AC (PP-2AC), purified according to Usui et al. (38) by Dr. D. L. Brautigan (Providence, RI), was used to dephosphorylate serine and threonine residues of IRS- 1 in vitro. Tyrosine phosphoproteins from both control and glucocorticoid-treated animals first were immunoprecipitated with $\alpha$-PY antibodies and protein A-agarose beads, as described above. The immunoprecipitates were washed three times in $50 \mathrm{mM}$ Hepes buffer $(\mathrm{pH} 7.6)$ containing $1 \%$ Triton X-100, $0.1 \%$ SDS, $100 \mathrm{mM}$ sodium fluoride, and $1 \mathrm{mM}$ sodium orthovanadate, and five times in $50 \mathrm{mM}$ Tris buffer ( $\mathrm{pH} 8.0$ ) containing $150 \mathrm{mM}$ $\mathrm{NaCl}$ and $1 \mathrm{mM}$ PMSF. Tyrosine phosphoproteins were eluted from the beads with $100 \mathrm{mM} \mathrm{HCl}$, neutralized to $\mathrm{pH} 7.8$ and incubated with $0.007 \mathrm{U} / \mu \mathrm{l} \mathrm{PP}-2 \mathrm{AC}$ in the presence of $1 \mathrm{mM} \mathrm{MgCl}_{2}$ and $30 \mathrm{mM} \beta$ mercaptoethanol for $1 \mathrm{~h}$ at $37^{\circ} \mathrm{C}$. Then, the samples were boiled in Laemmli buffer containing $100 \mathrm{mM}$ DTT, subjected to SDS-PAGE and immunoblotted with $\alpha$-IRS-1 antibody, as described above.

\section{Statistical analysis}

All data are presented as mean \pm SE. Statistical analyses were performed by paired and unpaired Student's $t$ tests.

\section{Results}

Experimental animals. Table I summarizes the body weights, plasma glucose, and plasma insulin concentrations of the experimental animals. As expected, the cortisone treatment regimen induced a catabolic state. Rats treated with cortisone ( $100 \mathrm{mg} /$ $\mathrm{kg}$, s.c.) for $5 \mathrm{~d}$ lost an average of $26 \pm 2 \mathrm{~g}$ in body weight over the 5 -d study period. The pair-fed controls gained $8 \pm 2 \mathrm{~g}$ over the same study period and, thus, the enhanced catabolism induced by glucocorticoid treatment and not the reduced food intake was responsible for the loss in body weight. When treated with glucocorticoids, STZ-treated animals showed a significantly greater decrease in body weight $(P<0.05)$ compared to pair-fed STZ-controls.

Plasma glucose concentrations in glucocorticoid-treated animals measured between 9:30 and 11:00 a.m. in the non- 
fasted state were clearly elevated into the hyperglycemic range (Table I, group a.). In these animals, the presence of insulin resistance was confirmed by the simultaneous occurrence of markedly elevated plasma insulin concentrations. Animals treated with a single dose of STZ were also markedly hyperglycemic. Despite the presence of hyperglycemia, nonfasted plasma insulin concentrations in these STZ-treated rats were not elevated and were not changed significantly by $5 \mathrm{~d}$ of cortisone treatment (Table I, group b.).

Because glucocorticoid excess is known to induce a decrease in muscle protein, we measured muscle DNA content as an index of muscle cell number. After $5 \mathrm{~d}$ of treatment with cortisone, the mean hindlimb muscle DNA/protein ratio was slightly higher but not significantly different from pair-fed controls ( $7.9 \pm 0.7$ vs. $6.7 \pm 0.7 \mu \mathrm{g} / \mathrm{mg}$ muscle protein, NS).

Insulin-stimulated tyrosine phosphorylation. To investigate the effects of glucocorticoid excess on insulin-stimulated tyrosine phosphorylation, rats were studied after $5 \mathrm{~d}$ of cortisone treatment and compared to pair-fed controls. To maximally stimulate protein tyrosine phosphorylation in skeletal muscle, insulin was injected via cardiac puncture at the dose of 10 $\mathrm{U} / \mathrm{kg}$ body weight, and hindlimb muscles were rapidly harvested after $2 \mathrm{~min}$ and frozen in liquid $\mathrm{N}_{2}$. This dose of insulin and the 2-min time point were chosen because a maximally effective stimulation of both insulin receptor and substrate phosphorylation is observed in control animals under these experimental conditions (26). Muscle tissue was subsequently homogenized under highly denaturing conditions (1\% SDS plus $50 \mathrm{mM} \mathrm{DTT}$, at $100^{\circ} \mathrm{C}$ ) to prevent the occurrence of phosphatase-mediated dephosphorylation (18). Tyrosine phosphoproteins were precipitated with $\alpha$-PY antibody and subsequently identified with $\alpha$-PY antibody and ${ }^{125} \mathrm{I}$-protein A on immunoblots. Equal amounts of muscle protein from control and glucocorticoid-treated animals were used for the immunoprecipitation experiments. The immunoprecipitation step was necessary both to concentrate the proteins of interest and to remove other more abundant muscle proteins (e.g., myosin ) that may interfere with detection and quantitation of specific bands on immunoblots.

Insulin injection resulted in the stimulation of tyrosine phosphorylation of two major proteins with $M_{\mathrm{r}}$ of 95,000 (pp95) and 170,000 (pp170) in both control and glucocorticoid-treated animals. Fig. 1 is a representative autoradiograph in which each lane was derived from the muscle of a single animal. In the muscle protein from the glucocorticoid-treated animal, a change in the electrophoretic migration of $\mathrm{pp} 170$ is evident, with the apparent $M_{\mathrm{r}}$ reduced by $\sim 10 \mathrm{kD}$. This change in the electrophoretic mobility of pp170 in glucocorticoid-treated animals was a consistent finding in all experiments.

Based on their apparent $M_{\mathrm{r}}$, the tyrosine phosphoproteins pp95 and pp 170 observed in immunoblots with $\alpha$-PY antibody were hypothesized to represent the insulin receptor $\beta$ subunit and the insulin receptor substrate IRS-1, respectively. To test this hypothesis, specific antibodies to the carboxy-terminal region of the rat insulin receptor $\beta$ subunit $(\alpha$-IRCt) and the carboxy-terminal region of rat IRS-1 ( $\alpha$-IRS- 1 ) were used to specifically identify the two proteins in $\alpha$-PY precipitates. In the experiment shown in Fig. 2, $\alpha$-PY precipitates of muscle proteins from both control and glucocorticoid-treated animals were resolved on SDS-PAGE in triplicate and subsequently

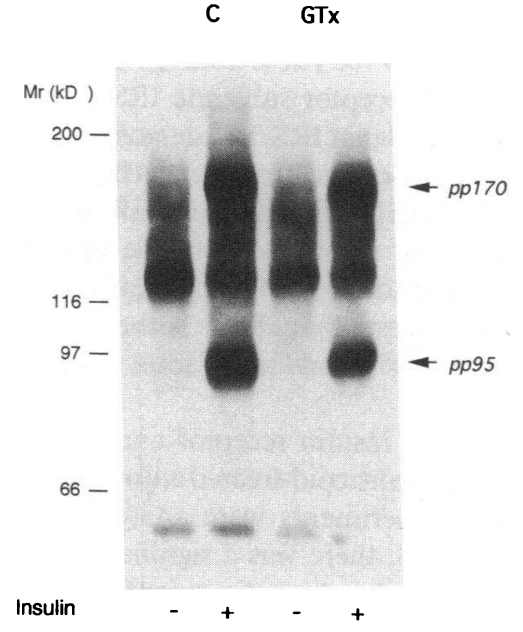

Figure 1. Effects of insulin stimulation on in vivo tyrosine phosphorylation of cellular proteins from skeletal muscle of control $(C)$ and glucocorticoid-treated $(G T x)$ rats. GTx rats were treated with cortisone for $5 \mathrm{~d}$ and compared with pair-fed controls. Either saline or a maximally effective dose of insulin $(10 \mathrm{U} /$ $\mathrm{kg}$ body $\mathrm{wt}$ ) was injected via cardiac puncture. After 2 min, hindlimb skeletal muscle was removed, frozen, and

solubilized as described in Methods. Tyrosine phosphoproteins were immunoprecipitated with $\alpha$-PY antibody, separated by SDS-PAGE, and identified by immunoblotting with $\alpha$-PY antibody and ${ }^{125} \mathrm{I}$-protein A. Each lane in this autoradiograph contains $\alpha$-PY precipitates from an equal amount of muscle protein from an individual animal. In each pair, the left lane represents a saline-injected and the right lane an insulin-injected rat.

blotted with either $\alpha$-PY, $\alpha$-IRCt, or $\alpha$-IRS- 1 antibodies in parallel. Of the muscle tyrosine phosphoproteins immunoprecipitated by $\alpha$-PY, $\alpha$-IRCt identified a single sharp band that comigrated with pp95 in both control and glucocorticoid-treated animals, indicating that the insulin-stimulated $M_{\mathrm{r}} 95,000$ tyrosine phosphoprotein ( $\mathrm{pp} 95$ ) is the $\beta$ subunit of the insulin receptor. On the other hand, the antibody specific to the IRS-1 protein, $\alpha$-IRS-1, reacted with a single species that had the same molecular mass as pp170. Noteworthy, in the glucocorticoid-treated animal, the $\alpha$-IRS-1-reactive protein showed in-

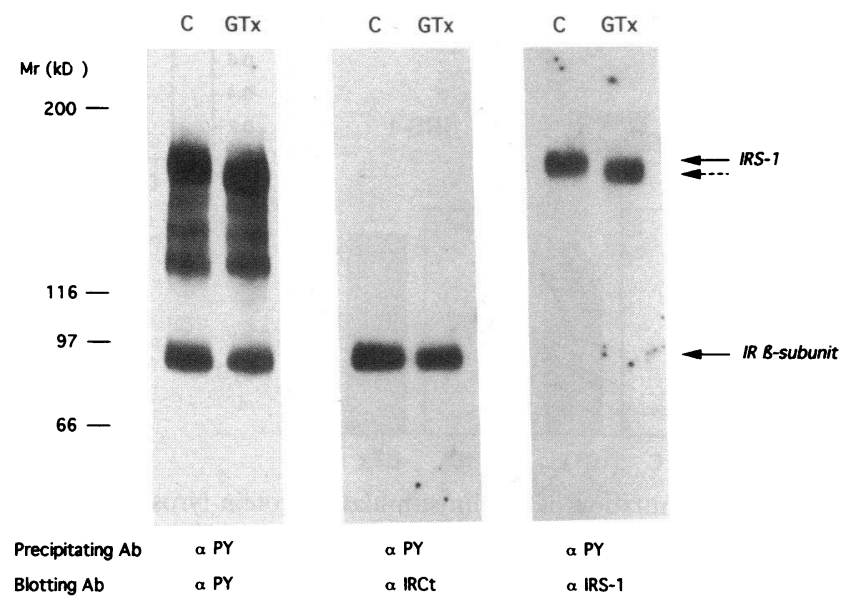

Figure 2. Identity of insulin-stimulated tyrosine phosphoproteins in the skeletal muscle of control $(C)$ and glucocorticoid-treated $(G T x)$ rats. Solubilized muscle proteins from insulin-injected control and cortisone-treated animals were immunoprecipitated with $\alpha$-PY antibody, resolved by SDS-PAGE in triplicate, and then immunoblotted with either $\alpha$-PY, an antibody specific to the carboxy-terminal region of the insulin receptor (IR) $\beta$-subunit ( $\alpha$-IRCt), or an antibody specific to the carboxy-terminal region of rat IRS-1 ( $\alpha$-IRS- 1$)$. 
creased elecrophoretic mobility, with its apparent $M_{\mathrm{r}}$ reduced by $8-10 \mathrm{kD}$, as noted above for pp 170 . These findings indicate that the recently cloned insulin receptor substrate IRS- 1 is a component of the pp 170 band, and that IRS- 1 undergoes covalent modifications during glucocorticoid treatment which result in a reduced apparent $M_{\mathrm{r}}$ on SDS-PAGE. The shift in the electrophoretic mobility affecting simultaneously the pp170 recognized by the PY antibody and the protein recognized by the IRS- 1 antibody strongly suggests that IRS- 1 is the dominant or sole component of the pp 170 band in rat adult skeletal muscle.

To quantitate the changes in insulin receptor and IRS-1 tyrosine phosphorylation in glucocorticoid-treated animals, autoradiographs from multiple experiments were analyzed by densitometry. As shown in Fig. 3, there was a significant decrease in the level of insulin-stimulated insulin receptor tyrosine phosphorylation $(69 \pm 4 \%$ of controls, $P<0.05)$ in the skeletal muscle of animals treated with cortisone for $5 \mathrm{~d}$. The level of tyrosine phosphorylation of IRS-1 was not significantly altered by the glucocorticoid-treatment $(88 \pm 5 \%$ of controls, NS). However, in a limited group of animals in which the glucocorticoid treatment regimen was associated with a more pronounced hyperinsulinemic response (insulin levels $>180$ $\mu \mathrm{U} / \mathrm{ml}$ ), IRS-1 tyrosine phosphorylation was modestly but significantly reduced ( $\sim 25 \%, P<0.05$, data not shown $)$. As shown in the inset of Fig. 3, quantitation of IRS-1 phosphorylation relative to the degree of insulin receptor phosphorylation did not show any significant difference between glucocorticoidtreated and control animals.

Muscle content of insulin receptors and IRS-1 and efficiency of tyrosine phosphorylation. The decrease in the total level of insulin receptor tyrosine phosphorylation in glucocorticoidtreated skeletal muscle could reflect a reduced number of tyro-

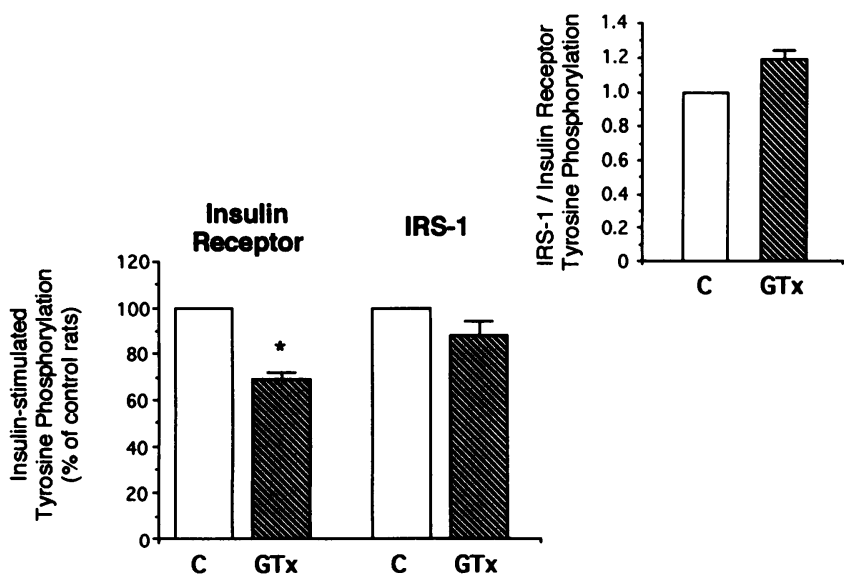

Figure 3. Quantitation of insulin-stimulated protein tyrosine phosphorylation in skeletal muscle of control $(C)$ and cortisone-treated $(G T x)$ rats. Animals were injected with $10 \mathrm{U}$ insulin/ $\mathrm{kg}$ body wt and, after 2 min, hindlimb skeletal muscles were removed and frozen in liquid $\mathrm{N}_{2}$. Tyrosine phosphoproteins were analyzed as described in Methods. Autoradiographs of $\alpha$-PY immunoblots from multiple experiments were subjected to scanning densitometry, and the levels of insulin receptor and IRS- 1 tyrosine phosphorylation quantified. Each lane in the autoradiographs contained $\alpha$-PY precipitates from an equal amount of muscle protein from an individual animal. The inset shows the ratio of IRS-1 phosphorylation to insulin receptor phosphorylation in the experimental groups. ${ }^{*} P<0.05$ vs. $\mathrm{C}$, unpaired $t$ test. sine residues phosphorylated in each individual receptor molecule and/or a decrease in the population of receptors that undergo tyrosine phosphorylation. These two possibilities were investigated by measuring the total quantity of receptors as well as the quantity of in vivo tyrosine phosphorylated receptors in the skeletal muscle of hypercortisolemic animals compared to controls.

In immunoprecipitation experiments using muscle protein extracts from both control and glucocorticoid-treated animals, the $\alpha$-PY antibody was found to precipitate $\sim 90 \%$ and $80 \%$ of the tyrosine phosphorylated insulin receptors and IRS-1 present in the extracts, respectively (data not shown). To assess whether the efficiency of precipitation by the $\alpha$-PY antibody was dependent on the extent of receptor phosphorylation, we compared the ability of $\alpha$-PY to immunoprecipitate partially phosphorylated and fully phosphorylated insulin receptors that were labeled with ${ }^{32} \mathrm{P}$ and added to the muscle extracts. Insulin receptors with phenylalanine replacing tyrosine-1146, one of the major tyrosine phosphorylation sites in the receptor $\beta$ subunit, were used as a source of partially phosphorylated insulin receptors. These mutant receptors are characterized by a reduced stoichiometry of tyrosine autophosphorylation compared to wild-type receptors (37). Mutant as well as wild-type insulin receptors were partially purified, incubated with 100 $\mathrm{nM}$ insulin, and autophosphorylated in vitro in the presence of $\left[{ }^{32} \mathrm{P}\right]$ ATP. Then, they were mixed with muscle protein extracts from the experimental animals and subjected to immunoprecipitation with $\alpha$-PY antibody. Greater than $95 \%$ of both the wild-type and tyrosine-1146 mutated receptors were precipitated by the $\alpha$-PY antibody. This was assessed by comparing the amount of ${ }^{32} \mathrm{P}$-labeled receptors precipitated and remaining in the supernatants after immunoprecipitation. The autoradiograph in Fig. 4 shows a representative experiment. Similar re-

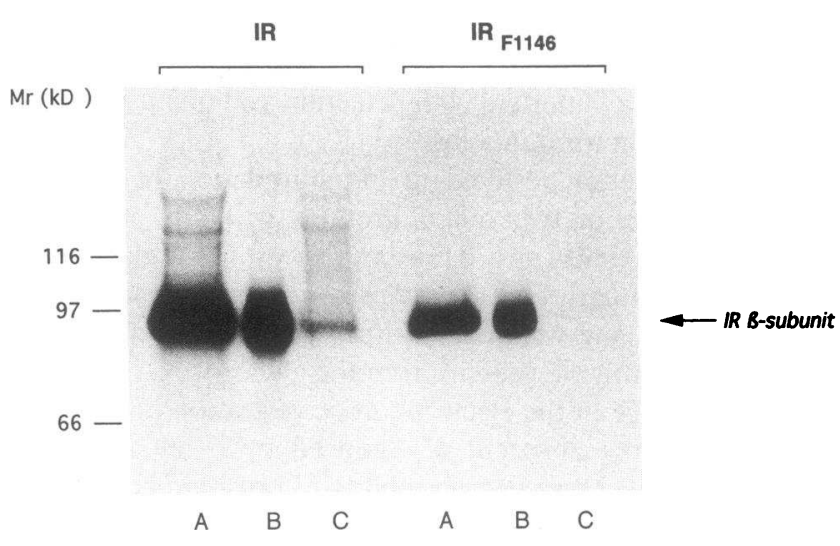

Figure 4. Effectiveness of immunoprecipitation of insulin receptors with different degrees of tyrosine phosphorylation by the $\alpha$-PY antibody. Wheat germ-purified insulin receptors from $\mathrm{CHO} / \mathrm{IR}$ and $\mathrm{CHO} / \mathrm{IR}_{\mathrm{F} 1146}$ cells were adjusted to equal amounts of protein and incubated for $60 \mathrm{~min}$ in the presence of $100 \mathrm{nM}$ insulin. Autophosphorylation was initiated by adding $10 \mu \mathrm{M}\left[\gamma_{-}{ }^{32} \mathrm{P}\right]$ ATP for $30 \mathrm{~min}$ at $23^{\circ} \mathrm{C}$. Phosphorylated receptors were mixed with muscle protein extracts as described in the Methods and analyzed by SDS-PAGE under reducing conditions (7\% resolving gel) and autoradiography. $\mathrm{IR}$, insulin receptors from $\mathrm{CHO} / \mathrm{IR}$ cells; $\mathrm{IR}_{\mathrm{F} 1146}$, insulin receptors from $\mathrm{CHO} / \mathrm{IR}_{\mathrm{F} 1146}$ cells. Lanes $A$, nonimmunoprecipitated material; lanes $B$, material immunoprecipitated with $\alpha$-PY antibody; lanes $C$, supernatant from $\alpha$-PY antibody immunoprecipitates. 
sults were obtained with partially purified wild-type and mutant insulin receptors not mixed with muscle extracts (data not shown). These findings indicate that insulin receptors known to have different degrees of phosphorylation are immunoprecipitated with equal and high efficiency from muscle protein extracts by the $\alpha$-PY antibody.

To estimate the total quantity of insulin receptors present in the muscle protein extracts independent of phosphorylation state, the anti-insulin receptor antibody $\alpha$-IRCt, generated against the carboxy-terminal amino acid sequence of the rat insulin receptor, was used as previously described (26). Equal amounts of solubilized muscle protein from the experimental animals were subjected to immunoprecipitation with $\alpha$-IRCt. Subsequently, $\alpha$-IRCt precipitates were resolved by SDSPAGE under reducing conditions and then immunoblotted with $\alpha$-IRCt and ${ }^{125}$ I-protein A. A representative autoradiograph of experiments performed according to this procedure is shown in Fig. $5 A$. The single sharp band at $M_{\mathrm{r}} 95,000$ represents the $\beta$ subunit of the insulin receptor. Quantitative analysis of multiple experiments, illustrated in Fig. $5 C$, indicated that the total levels of insulin receptor protein were increased by $36 \%(P<0.05)$ in the skeletal muscle of hypercortisolemic animals compared to controls. To determine the number of tyrosine phosphorylated receptors, experiments were conducted in parallel using muscle protein extracts from the same experimental animals. Receptors containing phosphorylated tyrosine residues were selectively immunoprecipitated with $\alpha$ PY antibody, and the amount of receptor protein in these $\alpha$-PY precipitates was then quantitated by immunoblotting with the $\alpha$-IRCt antibody. A representative experiment is presented in Fig. $5 \mathrm{~B}$, and the result of quantitative analysis of multiple experiments in Fig. $5 \mathrm{D}$. The quantity of tyrosine phosphorylated receptors was significantly reduced in glucocorticoid- treated animals compared to controls. Since the decrease in tyrosine phosphorylated receptors $(35 \%)$ is approximately equal to the decrease in total insulin receptor tyrosine phosphorylation ( $36 \%$, Fig. 3 ), we conclude that decreased insulin receptor tyrosine phosphorylation in the glucocorticoid-treated animals reflects a reduced number of receptors undergoing tyrosine phosphorylation rather than a reduced number of phosphotyrosines per receptor molecule. To further investigate the mean stoichiometry of insulin receptor phosphorylation in vivo, we determined the ratio of tyrosine phosphorylated receptors to total receptors in each individual animal. As shown in Fig. $5 E$, the ratio was markedly decreased by glucocorticoid treatment $(56.7 \pm 4 \%$ of control, $P<0.05$ ). These findings further establish the existence of an increased population of unphosphorylated insulin receptors in the skeletal muscle of animals treated with glucocorticoids.

With a similar experimental approach, the amounts of total as well as tyrosine phosphorylated substrate IRS-1 were determined in the skeletal muscle of the experimental animals (Fig. 6 ). To measure the total amount of IRS-1, solubilized muscle proteins from glucocorticoid-treated and control animals were subjected to sequential immunoprecipitation and immunoblotting with antibody specific to rat IRS-1 (20). The antibody preparation used for these experiments has been demonstrated to react with IRS-1 independent of the phosphorylation state of the protein (data not shown). As evident from both the representative autoradiograph presented in Fig. $6 \mathrm{~A}$, and the corresponding quantitative analysis of multiple experiments (Fig. 6 $C)$, glucocorticoid excess resulted in a marked decrease in the total amount of IRS-1 protein in skeletal muscle $(50.3 \pm 13 \%$ of controls, $P<0.05$ ). The amount of in vivo tyrosine phosphorylated IRS- 1 was measured by immunoprecipitating with $\alpha$-PY antibody and then immunoblotting with $\alpha$-IRS-1 antibody. A

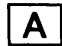

C GTX

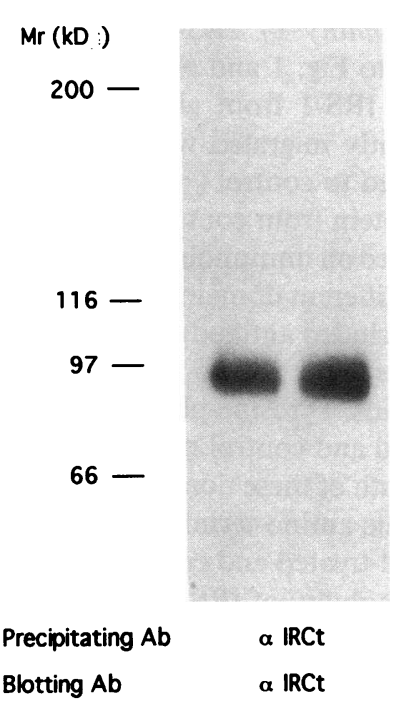

B




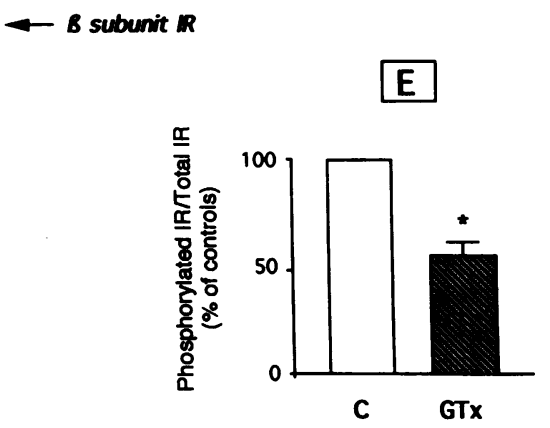

Figure 5. Total insulin receptors and tyrosine phosphorylated receptors after maximal insulin stimulation in control $(C)$ and glucocorticoidtreated $(G T x)$ animals. To measure the total quantity of insulin receptors (IR) present in the muscle protein extracts, equal amounts of solubilized muscle protein from the experimental animals were immunoprecipitated with $\alpha$-IRCt antibody. Subsequently, $\alpha$-IRCt precipitates were resolved by SDSPAGE under reducing conditions and then immunoblotted with $\alpha$ IRCt and ${ }^{125}$ I-protein A (panel $A$ ). To measure the quantity of tyrosine phosphorylated receptors, aliquots of the same muscle protein extracts were subjected to immunoprecipitation with $\alpha$-PY antibody, and the amount of receptor protein in these precipitates was then quantitated by immunoblotting with the $\alpha$-IRCt antibody (panel $B$ ). Results of quantitative analysis of multiple experiments performed according to

the two procedures are shown in $C$ and $D$, respectively. The graph in panel $E$ illustrates the ratio between in vivo phosphorylated insulin receptors and total receptors in the skeletal muscle from $\mathrm{C}$ and GTx rats. ${ }^{*} P<0.05$ vs. C, paired $t$ test. 


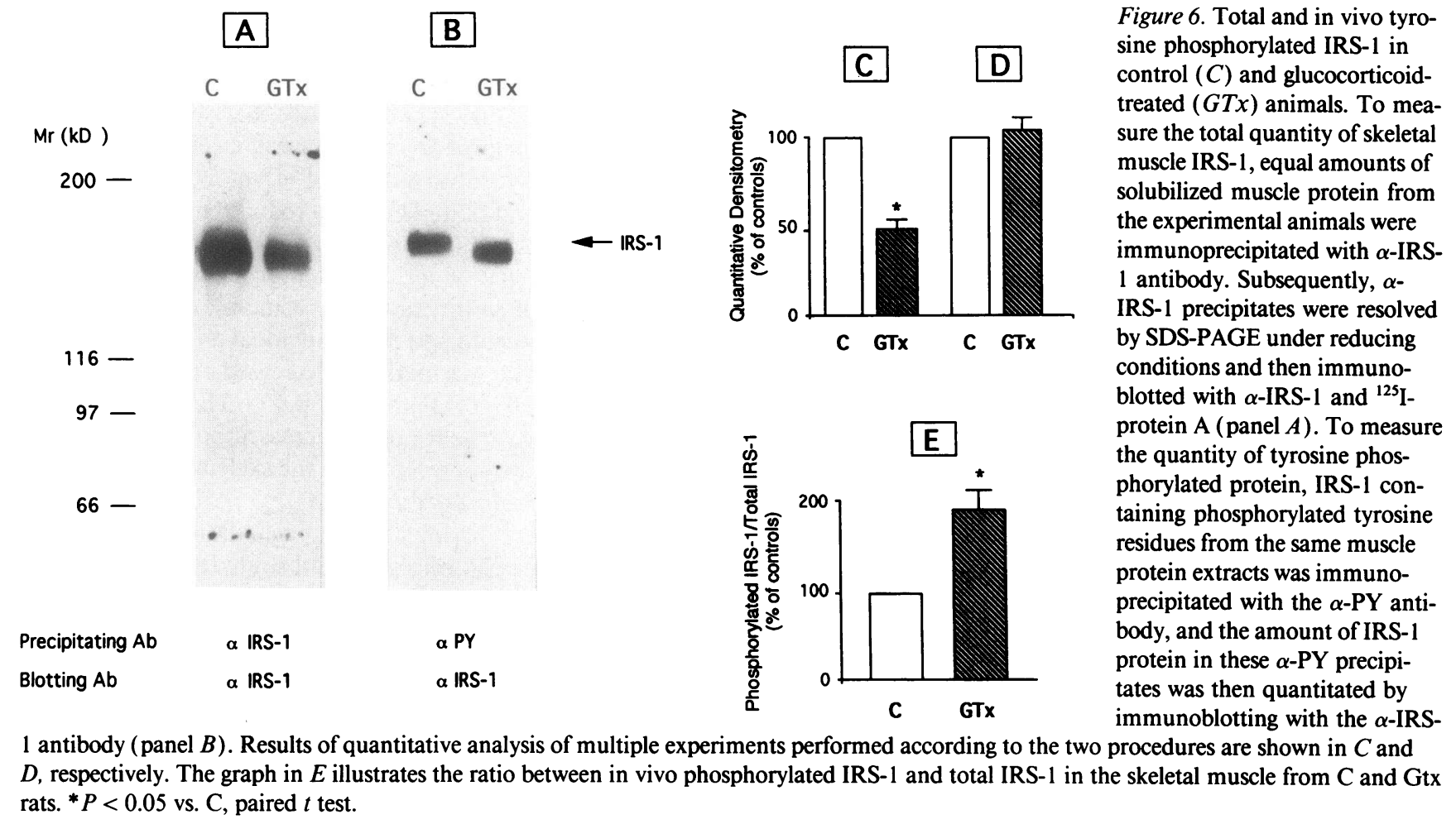

representative experiment is presented in Fig. $6 \mathrm{~B}$, and the quantitative analysis in Fig. $6 \mathrm{D}$. Despite the decreased total muscle content of IRS-1, the amount of tyrosine phosphorylated IRS-1 was unchanged by glucocorticoid treatment. This is consistent with the lack of change in the total amount of tyrosine phosphorylation of IRS-1, measured by $\alpha$-PY antibody immunoprecipitation and blotting (Fig. 3). Taken together, these results indicate that the total amount of IRS-1 tyrosine phosphorylation and the total pool of IRS-1 molecules that undergo tyrosine phosphorylation in response to insulin stimulation in vivo are unaltered by glucocorticoid treatment. Since the total muscle content of IRS- 1 is decreased by glucocorticoid treatment, however, a greater fraction of IRS-1 must be tyrosine phosphorylated in glucocorticoid-treated animals. This is illustrated in Fig. $6 E$, where the ratio of tyrosine phosphorylated IRS-1 to total IRS-1 is illustrated. The ratio is increased approximately twofold in the skeletal muscle of hypercortisolemic animals.

Effects of glucocorticoids on protein tyrosine phosphorylation in insulin-deficient animals. To investigate the role of hyperinsulinemia in the glucocorticoid response, animals were made insulin-deficient with STZ ( $100 \mathrm{mg} / \mathrm{kg}$, i.p.) and subsequently treated with cortisone acetate $(100 \mathrm{mg} / \mathrm{kg}$, s.c.) for $5 \mathrm{~d}$. Pair-fed STZ-treated animals were used as controls. Cortisone treatment of STZ-animals had no effect on insulin levels ( Table I) and did not significantly alter either insulin receptor or IRS-1 tyrosine phosphorylation $(84.7 \pm 4 \%$ and $111.7 \pm 11 \%$ of controls, respectively, NS)(Fig. 7, top panel). Also, no changes in the molecular weight of IRS-1 were observed with glucocorticoid treatment of STZ-rats (data not shown). Cortisone treatment of STZ-animals did not significantly alter the total quantity of insulin receptors, but significantly increased the total amount of IRS- 1 in skeletal muscle $(179 \pm 14 \%$ of levels in STZ-

animals, $P<0.05$ ) (Fig. 7, bottom panel). The increase in the total amount of IRS-1 protein after cortisone treatment of STZ animals is in contrast with the effects of this steroid agent on non-STZ rats (see above) and also differs from the effects of STZ-diabetes per se (39), both of which result in a decreased amount of IRS-1 protein in skeletal muscle. These experiments indicate that hyperinsulinemia is a necessary component for the effects of glucocorticoids on both tyrosine phosphorylation and protein levels of the insulin receptor and IRS-1 in rat skeletal muscle.

Increased electrophoretic mobility of IRS-1. As noted above in the comments relating to Fig. 1 and evident also in Fig. 2, tyrosine phosphorylated IRS-1 from glucocorticoidtreated skeletal muscle consistently migrated with increased mobility on SDS-PAGE compared to control ( $\sim 160$ vs. 170 $\mathrm{kD}$, respectively). The IRS-1 protein from control and glucocorticoid-treated animals interacted on immunoblots with multiple antibodies directed against different domains of the molecule. As shown in Fig. 8, these included antibody preparations specific to the last 14 carboxy-terminal amino acids and the first 12 amino-terminal amino acids. Tyrosine-phosphorylated IRS-1 from glucocorticoid-treated and control muscle reacted equally well with antibodies to both of these domains, indicating that the carboxy- as well as the amino-terminal regions of IRS-1 are intact in glucocorticoid-treated and control muscle.

The altered electrophoretic mobility of IRS- 1 after glucocorticoid administration could result from a decrease in phosphorylation of the protein. The increased electrophoretic mobility of IRS-1 in glucocorticoid-treated animals was not associated with a change in phosphotyrosine content of the protein, but it could potentially be explained by reduced phosphorylation of serine and/or threonine residues. The published sequence of IRS- 1 contains 35 putative serine/threonine phos- 



Figure 7. Effects of glucocorticoid treatment on tyrosine phosphorylation (top panel) and total amounts (bottom panel) of insulin receptors and IRS- 1 in insulin-deficient animals. Rats were made insulin-deficient with STZ ( $100 \mathrm{mg} / \mathrm{kg}$, i.p.) and subsequently treated with cortisone acetate $(100 \mathrm{mg} / \mathrm{kg}$ body wt, s.c.) for $5 \mathrm{~d}$ (STZ

+ GTx). Pair-fed STZ-treated animals were used as controls (STZ). Anesthetized rats were injected with insulin ( $10 \mathrm{U} / \mathrm{kg}$ body wt) via cardiac puncture. After $2 \mathrm{~min}$, hindlimb muscle was harvested and processed as described in Methods for identification of tyrosine phosphorylated proteins. Autoradiographs of $\alpha$-PY immunoblots from multiple experiments were subjected to scanning densitometry, and the levels of insulin receptor and IRS-1 tyrosine phosphorylation quantified. The total amounts of insulin receptors and IRS-1 were quantitated with specific antibodies to these proteins as described in the Methods. Data are expressed as a percentage of values in STZ controls.

phorylation sites distributed throughout the protein (20), and serine as well as threonine phosphorylation of IRS- 1 has been shown to occur in intact cells (20). To investigate the effects of serine/threonine dephosphorylation on the electrophoretic mobility of IRS-1, muscle protein extracts from insulin-stimulated hypercortisolemic and control animals were subjected to immunoprecipitation with $\alpha$-PY antibody and then incubated with protein phosphatase-2AC (PP-2AC), a specific serine/ threonine phosphatase (38). The protein products were resolved by SDS-PAGE, and IRS- 1 identified with $\alpha$-IRS- 1 antibody on immunoblots. As shown in Fig. 9, treatment with
C GTx

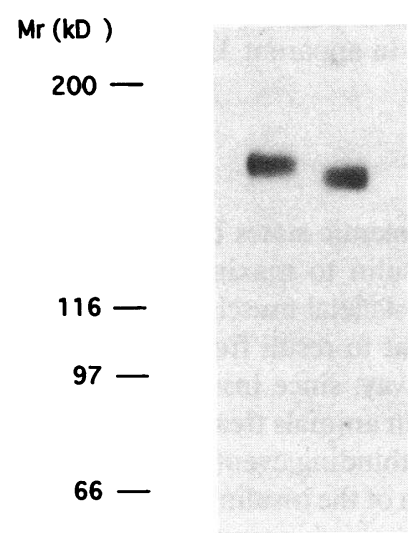

Precipitating Ab

Blotting Ab

\section{GTX}

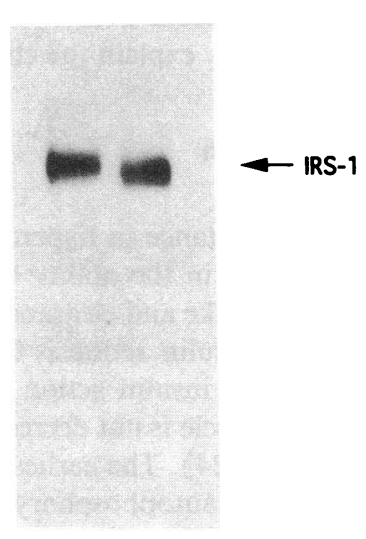

Figure 8. Comparative immunoreactivity of skeletal muscle IRS-1 with antibodies against distinct domains of the IRS-1 protein. Solubilized muscle proteins from insulin-injected control $(C)$ and cortisone-treated $(G T x)$ animals were immunoprecipitated with $\alpha$-PY antibody, resolved by SDS-PAGE in duplicate, and then immunoblotted with either an antibody specific to the carboxy-terminal region of rat IRS-1 ( $\alpha-I R S-1 C t)$, or an antibody specific to the amino-terminal region of rat IRS-1 $(\alpha-I R S-1 N t)$.

PP-2AC increased the electrophoretic mobility of IRS-1 from control muscle. After treatment with PP-2AC, the apparent $M_{\mathrm{r}}$ of IRS-1 was similar to that in glucocorticoid-treated muscle. By contrast, treatment with PP-2AC did not significantly affect the mobility of the protein from glucocorticoid-treated muscle. Treatment with PP-2AC did not alter the phosphotyrosine content of IRS-1, as assessed by immunoblotting with $\alpha$-PY antibody in parallel (data not shown). These data indicate that a reduction in the apparent $M_{\mathrm{r}}$ of IRS-1 on SDS-PAGE can be produced by specific serine and/or threonine dephosphorylation of the protein. The magnitude of the $M_{\mathrm{r}}$ shift with dephosphorylation is similar to the decrease in $M_{\mathrm{r}}$ that occurs with glucocorticoid treatment. Since PP-2AC does not alter the electrophoretic mobility of IRS-1 from muscle of glucocorticoidtreated animals, we conclude that the phosphoserine and/or

Figure 9. Dephosphorylation of IRS-1 by PP2AC. Solubilized muscle proteins from insulin-injected control $(C)$ and cortisone-treated $(G T x)$ animals were immunoprecipitated with $\alpha$-PY antibody, and incubated in the presence or absence of $0.007 \mathrm{U} / \mu \mathrm{l} \mathrm{PP}-2 \mathrm{AC}$, as described in Methods. The protein products were then resolved by SDS-PAGE and immunoblotted with $\alpha$-IRS- 1 antibody. 
phosphothreonine content of IRS- 1 must be significantly lower in glucocorticoid-treated animals compared to controls and that this may explain the change in apparent $M_{\mathrm{r}}$.

\section{Discussion}

Insulin resistance in hypercortisolemic states is characterized by a defect in the ability of insulin to maximally stimulate glucose uptake and clearance by skeletal muscle $(2,5,6)$. The defect in insulin action is thought to result from postbinding steps in the insulin action pathway, since insulin binding in skeletal muscle is not decreased in animals treated with glucocorticoids (24). The earliest postbinding events in insulin action involve autophosphorylation of the insulin receptor $\beta$ subunit, activation of the receptor tyrosine kinase, and subsequent phosphorylation of intracellular substrate proteins (7-11). The objective of this study was to explore the effects of glucocorticoid excess on these initial postbinding events in insulin signaling in rat skeletal muscle in vivo. By measuring in vivo tyrosine phosphorylation of insulin receptors and the major cellular substrate IRS-1, we have been able to demonstrate that glucocorticoid excess results in abnormalities in insulin signaling at both receptor and postreceptor levels.

Administration of glucocorticoids resulted in a reduced level of total tyrosine phosphorylation of the insulin receptor ( 35\% less than control) measured with phosphotyrosine antibody after maximal insulin stimulation. In contrast, the insulin receptor content in skeletal muscle, measured with insulin receptor antibody, was moderately increased. Thus, there appears to be a defect in the ability of skeletal muscle receptors to undergo insulin-stimulated tyrosine phosphorylation in vivo in the presence of hypercortisolemia. In subsequent experiments, the decrease in receptor phosphorylation was shown to be characterized by a lower number of receptors undergoing tyrosine phosphorylation rather than a reduced extent of tyrosine phosphorylation per receptor. Therefore, glucocorticoid treatment results in an increased proportion of unphosphorylatable receptors in skeletal muscle, despite the fact that the total muscle content of insulin receptors is increased.

Our results are in apparent contrast with a previous study by Block and Buse (24) on insulin receptor tyrosine kinase activity in skeletal muscle of hypercortisolemic animals that showed normal receptor autophosphorylation and kinase activity. The differences between the two studies may be explained by the distinct experimental methods used to assess insulin receptor tyrosine kinase activity. Although insulin stimulation was performed in vivo with an intravenous injection in the study by Block and Buse (24), receptor phosphorylation was studied in vitro in a cell-free system. In our experimental system, insulin-stimulated receptor phosphorylation occurred entirely in vivo, under conditions where the integration of receptors into muscle tissue structure was preserved. It is conceivable that the decreased fraction of tyrosine phosphorylated receptors in muscle of glucocorticoid-treated animals reflects their altered subcellular distribution and accessibility to insulin binding. On solubilization, insulin may gain access to all receptors, and the phosphorylation defect thus may no longer be evident. Our study also differs from that of Block and Buse (24) in that we used a pair-feeding protocol to assure equal food intake in control and glucocorticoid-treated animals. A decrease $(\sim 40 \%)$ in food intake occurs when high doses of glucocorticoids are administered, and this could influence protein tyrosine phosphorylation per se. It is important to consider in this regard that fasting and feeding have been shown to regulate insulin receptor phosphorylation in rat liver and muscle both in vitro (40) and in vivo (39). Moreover, the effects of glucocorticoids on insulin receptor kinase activity have been shown to be profoundly modulated by the dietary state of the animal (41).

We have presented evidence that the population of skeletal muscle insulin receptors capable of undergoing tyrosine phosphorylation in response to insulin stimulation in vivo is reduced following glucocorticoid treatment. These findings suggest the existence of two distinct population of receptors, one capable of undergoing tyrosine phosphorylation and one unable to autophosphorylate in response to insulin. The phosphorylatable pool appears to decrease and the unphosphorylatable pool to increase in association with glucocorticoid-induced insulin resistance. The existence of a pool of "kinase-silent" receptors has previously been demonstrated by Pang et al. (42) in Fao cells, where this pool appears to represent $>50 \%$ of total cellular insulin receptors. In another study, Brillon et al. (43) photoaffinity-labeled insulin receptors from normal and non-insulin-dependent diabetic subjects and then used $\alpha$-PY and $\alpha$-IRCt to discriminate between receptors capable of autophosphorylation in vitro and receptors that could not be phosphorylated. These authors showed that the pool of kinase-defective insulin receptors is increased in adipocytes from insulin-resistant diabetic subjects and suggested that this provides an explanation for the defect in insulin receptor kinase activity observed in these patients. They concluded that impaired tyrosine phosphorylation is an intrinsic biochemical feature of the subpopulation of receptors and suggested that the defect in receptor phosphorylation could derive from an increase in the ATP $K_{\mathrm{m}}$, resulting in less phosphate transferred to the receptors, or from an increase in serine phosphorylation of the insulin receptor, which has been shown to inhibit insulinstimulated tyrosine phosphorylation of the $\beta$ subunit (44).

To explain the increase in the population of receptors that do not undergo tyrosine phosphorylation in response to insulin in our in vivo system, an additional mechanism can be hypothesized. While it is unlikely that decreased receptor phosphorylation reflects differences in binding affinity for insulin, since the insulin dose that we used to stimulate tyrosine phosphorylation was maximally effective for both control and hypercortisolemic animals, it is possible that a fraction of the insulin receptors are not available for insulin binding and subsequent activation because they are not at the cell surface. Animals treated with glucocorticoids were markedly hyperinsulinemic, and chronic hyperinsulinemia has been shown to induce "down-regulation" and loss of cell-surface receptors (45). The pattern of an increased total receptor content associated with a decreased proportion of "functional" receptors in skeletal muscle could reflect the product of the in vivo interplay between glucocorticoid excess and hyperinsulinemia, whereby glucocorticoids act to increase insulin receptor expression (46) and insulin opposes this phenomenon by promoting receptor down-regulation. The importance of hyperinsulinemia for the glucocorticoid response is supported by the observation that insulin receptor phosphorylation was not decreased when the glucocorticoid excess was created in animals made insulin-deficiency by STZ administration. 
Glucocorticoid excess resulted in abnormalities in the insulin signaling pathway involving post-receptor steps including the expression and in vivo phosphorylation of the substrate IRS-1. IRS-1 is rapidly phosphorylated on tyrosine residues after insulin stimulation in intact cells (20) and this is thought to somehow lead to the next step(s) in insulin signaling. Sitedirected mutagenesis studies have demonstrated impaired insulin signaling by insulin receptors that undergo autophosphorylation normally but are incapable of mediating IRS-1 tyrosine phosphorylation $(47,48)$. Although this suggests a direct relationship between IRS-1 tyrosine phosphorylation and insulin action, we have recently demonstrated increased tyrosine phosphorylation of IRS-1 in the skeletal muscle of animals made diabetic and insulin-resistant by STZ administration (26). Similar results have been obtained in studies on liver tissue from STZ-diabetic animals (39). Therefore, the pathophysiologic significance of the levels of tyrosine phosphorylation of IRS- 1 in insulin-sensitive tissues remains uncertain

In glucocorticoid-treated, insulin-resistant animals, the skeletal muscle content of IRS-1 was decreased by $\sim 50 \%$. This response is similar to recently reported findings with 3T3-L1 adipocytes, in which dexamethasone down-regulated IRS-1 content by $60 \%$ and concomitantly caused insulin resistance (49). In spite of the decrease in IRS-1 content in the current study, neither the total level of tyrosine phosphorylation of IRS-1 nor the amount of tyrosine phosphorylated IRS-1 was significantly changed in glucocorticoid-treated animals. Thus, there must have been an increase in the extent of tyrosine phosphorylation per mole of IRS-1 in the presence of hypercortisolemia. In agreement with this phenomenon, Saad et al. have observed increased tyrosine phosphorylation of IRS-1, but decreased levels of the protein in the skeletal muscle of both fasted and STZ-diabetic animals (39). It can be concluded that in vivo tyrosine phosphorylation of IRS- 1 is regulated independent of changes in levels of the IRS-1 protein.

The increase in phosphorylation per mole of IRS-1 in glucocorticoid-treated animals contrasts with the decrease in tyrosine phosphorylation per mole of insulin receptor. A similar dissociation between changes in insulin receptor autophosphorylation and receptor kinase activity toward an artificial exogenous substrate has been described in insulin-resistant rat tissues $(29,40)$ and, in our recent work (26), a lack of correlation between changes in tyrosine phosphorylation of insulin receptors and IRS-1 was observed in the skeletal muscle of STZ-treated rats. It appears, therefore, that tyrosine phosphorylation of the insulin receptor and cellular substrates for the receptor can be independently regulated in vivo. These findings could be explained as a consequence of altered activity of specific phosphotyrosine phosphatases that, together with the receptor kinase, determine the level of tyrosine phosphorylation of IRS- 1 in the muscle cell.

Glucocorticoid treatment of rats resulted in a decrease in IRS-1 apparent $M_{\mathrm{r}}$ by $8-10 \mathrm{kD}$ on SDS-PAGE. This cannot be attributed to proteolytic clipping, since the protein is recognized by both carboxy-terminal and amino-terminal peptide antibodies. It also is unlikely to result from a different extent of glycosylation of the protein, since IRS- 1 is present in the cytosol (20), and glycosylation of intracellular proteins has not been reported. Dephosphorylation of IRS-1 from control muscle specifically at serine/threonine residues with PP-2AC resulted in a similar increase in electrophoretic mobility, whereas dephosphorylation had no effect on IRS-1 from glucocorti- coid-treated animals. Based on these findings, it appears that the reduced $M_{\mathrm{r}}$ of IRS-1 in the glucocorticoid-treated muscle reflects reduced phosphoserine and/or phosphothreonine content of the protein. This conclusion is supported by the previous observation that changes in the phosphorylation state of IRS-1 can affect its electrophoretic mobility. After insulin stimulation of CHO cells overexpressing insulin receptors, IRS-1 phosphorylation is enhanced due to an increase in both phosphotyrosine and phosphoserine content, and this is associated with slower migration of IRS-1 on SDS-PAGE (20). At present, the exact sites of phosphorylation of IRS-1 in vivo and their significance have not been determined. The association of IRS-1 with other intracellular proteins containing SH2 domains, including phosphatidylinositol 3-kinase, appears to require tyrosine phosphorylation of the protein (20). Phosphorylation of the insulin receptor on serine residues has been shown to inhibit insulin-stimulated tyrosine phosphorylation of the receptor $\beta$ subunit $(44,50)$ and insulin responses in intact cells (44). Although a role for serine and/or threonine phosphorylation of IRS-1 has not been established yet, it can be hypothesized that reduced phosphoserine and/or phosphothreonine content of IRS-1 may affect the function of this protein. In support of this concept, we have recently observed decreased insulin stimulation of IRS-1-associated phosphatidylinositol 3-kinase activity in glucocorticoid-treated rat skeletal muscle (F. Giorgino and R. J. Smith, unpublished observations). It will be important to investigate the pathophysiological relevance of this finding in the setting of glucocorticoidinduced insulin resistance.

In conclusion, the current study provides direct in vivo evidence that glucocorticoid-induced insulin resistance results in abnormalities in the intracellular signaling of insulin in skeletal muscle. The alterations are apparent at both receptor and postreceptor levels in the muscle cell. Insulin receptor tyrosine phosphorylation is decreased as a consequence of a decrease in the population of receptors capable of undergoing tyrosine phosphorylation. In addition, the expression of the endogenous insulin receptor substrate IRS-1 is decreased and the levels of serine and/or threonine phosphorylation of this protein are reduced. In further studies, it will be important to investigate the pathophysiological significance of these alterations and, in particular, the impact of changes in the phosphorylation state of IRS-1 on insulin action.

\section{Acknowledgments}

We gratefully acknowledge the provision of IRS-1 antibodies by Drs. G. E. Lienhard, C. R. Kahn, and M. F. White and the provision of PP-2AC by Dr. D. E. Brautigan. We are also indebted to Drs. P. A. Wilden and C. R. Kahn for providing the $\mathrm{CHO} / \mathrm{IR}$ and the $\mathrm{CHO} /$ $\mathrm{IR}_{\mathrm{F} 1146}$ cells.

This work was supported in part by grants from the Juvenile Diabetes Foundation, and the National Institutes of Health (Trauma Center Grant GM36428 and DERC Grant DK36836). F. Giorgino was supported by postdoctoral fellowships from the Consiglio Nazionale delle Ricerche (Italy) and the Juvenile Diabetes Foundation, and L. J. Goodyear was supported by National Institutes of Health Training Grant DK07260.

\section{References}

1. Amatruda, J. M., J. N. Livingstone, and D. H. Lockwood. 1985. Cellular mechanisms in selected states of insulin resistance: human obesity, glucocorticoid excess and chronic renal failure. Diabetes/Metab. Rev. 3:293-317. 
2. McMahon, M., J. Gerich, and R. Rizza. 1988. Effects of glucocorticoids on carbohydrate metabolism. Diabetes/Metab. Rev. 4:17-30.

3. Fain, J., R. Scow, and S. Chernick. 1963. Effects of glucocorticoids on metabolism of adipose tissue in vitro. J. Biol. Chem. 238:54-58.

4. Carter-Su, C., and K. Okamoto. 1985. Effect of glucocorticoids on hexose transport in rat adipocytes. J. Biol. Chem. 260:11091-11098.

5. Riddick, F., D. Reisler, and D. Kipnis. 1962. The sugar transport system in striated muscle. Diabetes. 11:171-178.

6. Haber, R. S., and S. P. Weinstein. 1992. Role of glucose transporters in glucocorticoid-induced insulin resistance. Diabetes. 41:728-735.

7. Goldfine, I. D. 1987. The insulin receptor: molecular biology and transmembrane signaling. Endocr. Rev. 8:235-255.

8. Kasuga, M., F. A. Karlsson, and C. R. Kahn. 1982. Insulin stimulates the phosphorylation of the $\beta$-subunit of its own receptor. Science (Wash. DC). 217:185-187.

9. Petruzzelli, L. M., S. Ganguly, C. J. Smith, M. U. Cobb, S. Rubin, and O. M. Rosen. 1982. Insulin activates a tyrosine-specific protein kinase in extracts of 3T3-L1 adipocytes and human placenta. Proc. Natl. Acad. Sci. USA. 79:67926796.

10. Yu, K. T., and M. P. Czech. 1984. Tyrosine phosphorylation of the insulin receptor $\beta$ subunit activates the receptor-associated tyrosine kinase activity. $J$. Biol. Chem. 259:5277-5286.

11. White, M. F., R. Maron, and C. R. Kahn. 1985. Insulin rapidly stimulates tyrosine phosphorylation of a $\mathrm{M}_{\mathrm{r}}-185,000$ protein in intact cells. Nature (Lond.). 318:183-186.

12. Kadowaki, T., S. Koyasu, E. Nishida, K. Tobe, T. Izumi, F. Takaku, H Sakai, I. Yahara, and M. Kasuga. 1987. Tyrosine phosphorylation of common and specific sets of cellular proteins rapidly induced by insulin, insulin-like growth factor I, and epidermal growth factor in an intact cell. J. Biol. Chem. 262:7342-7350.

13. Keller, S. R., K. Kitagawa, R. Aebersold, G. E. Lienhard, and C. W. Garner. 1991. Isolation and characterization of the 160,000-Da phosphotyrosyl protein, a putative participant in insulin signaling. J. Biol. Chem. 266:1281712820.

14. Haring, H. U., M. F. White, F. Machicao, B. Hermel, E. Schleicher, and B. Obermeier. 1987. Insulin rapidly stimulates phosphorylation of a 46-kDa membrane protein on tyrosine residues as well as phosphorylation of several soluble proteins in intact fat cells. Proc. Natl. Acad. Sci. USA. 84:113-117.

15. Beguinot, F., C. R. Kahn, A. C. Moses, M. F. White, and R. J. Smith 1989. Differentiation-dependent phosphorylation of a 175,000 molecular weight protein in response to insulin and insulin-like growth factor-I in L6 skeletal muscle cells. Endocrinology. 125:1599-1605.

16. Condorelli, G., P. Formisano, G. Villone, R. J. Smith, and F. Beguinot 1989. Insulin and insulin-like growth factor I (IGF-I) stimulate phosphorylation of a Mr 175,000 cytoskeleton-associated protein in intact FRTL5 cells. J. Biol. Chem. 264:12633-12638.

17. Tobe, K., O. Koshio, Y. Tashiro-Hashimoto, F. Takaku, Y. Akanuma, and M. Kasuga. 1990. Immunological detection of phosphotyrosine-containing proteins in rat livers after insulin injection. Diabetes. 39:528-533.

18. Rothenberg, P. L., W. S. Lane, A. Karasik, J. Backer, M. White, and C. R. Kahn. 1991. Purification and partial sequence analysis of pp 185, the major cellular substrate of the insulin receptor tyrosine kinase. J. Biol. Chem. 266:83028311.

19. Thies, R. S., J. M. Molina, T. P. Ciaraldi, G. R. Freidenberg, and J. M. Olefsky. Insulin-receptor autophosphorylation and endogenous substrate phosphorylation in human adipocytes from control, obese, and NIDDM subjects. Diabetes. 39:250-259.

20. Sun, X. J., P. Rothenberg, C. R. Kahn, J. M. Backer, E. Araki, P. A Wilden, D. A. Cahill, B. J. Goldstein, and M. F. White. 1991. Structure of the insulin receptor substrate IRS-1 defines a unique signal transduction protein. Nature (Lond.). 352:73-77.

21. Grunfeld, C., K. Baird, E. Van Obberghen, and C. R. Kahn. 1981. Glucocorticoid-induced insulin resistance in vitro: evidence for both receptor and postreceptor defects. Endocrinology. 109:1723-1730.

22. Caro, J. F., and J. M. Amatruda. 1982. Glucocorticoid-induced insulin resistance. The importance of postbinding events in the regulation of insulin binding, action and degradation in freshly isolated and primary cultures of rat hepatocytes. J. Clin. Invest. 69:865-875.

23. DePirro, R., A. Green, Y. Kao, and J. M. Olefsky. 1981. Effects of prednisolone and dexamethasone in vivo and in vitro: studies of insulin binding, deoxyglucose uptake, and glucose utilization in rat adipocytes. Diabetologia. 21:149153.

24. Block, N. E., and M. G. Buse. 1989. Effects of hypercortisolemia and diabetes on skeletal muscle insulin receptor function in vitro and in vivo. $\mathrm{Am}$. $\mathrm{J}$. Physiol. 256:E39-E48.

25. Truglia, J. A., G. R. Hates, and D. H. Lockwood. 1988. Intact adipocyte insulin receptor phosphorylation and in vitro tyrosine kinase activity in animal models of insulin resistance. Diabetes. 37:147-153.
26. Giorgino, F., J-H. Chen, and R. J. Smith. 1992. Changes in tyrosine phosphorylation of insulin receptors and a 170,000 molecular weight nonreceptor protein in vivo in skeletal muscle of streptozotocin-induced diabetic rats: effects of insulin and glucose. Endocrinology. 130:1433-1444.

27. Okamoto, M., M. F. White, R. Maron, and C. R. Kahn. 1986. Autophosphorylation and kinase activity of insulin receptor in diabetic rats. Am. J. Physiol. 251:E542-E550.

28. Kadowaki, T., M. Kasuga, Y. Akanuma, O. Ezaki, and F. Takaku. 1984. Decreased autophosphorylation of the insulin-receptor kinase in streptozotocindiabetic rats. J. Biol. Chem. 259:14208-14216.

29. Burant, C. F., M. K. Treutelaar, and M. G. Buse. 1986. Diabetes-induced functional and structural changes in insulin receptors from rat skeletal muscle. $J$. Clin. Invest. 77:260-270.

30. Goldstein, B. J., and A. L. Dudley. 1990. The rat insulin receptor: primary structure and conservation of tissue-specific alternative messenger RNA splicing. Mol. Endocrinol. 4:235-244.

31. Rannels, S. R., and L. S. Jefferson. 1980. Effects of glucocorticoids on muscle protein turnover in perfused rat hemicorpus. Am. J. Physiol. 238:E564E572.

32. Umpierrez, G. E., and R. G. Spanheimer. 1988. The use of glucose oxidase reagent strips to determine the metabolic status of diabetic animals. Lab. Anim. Sci. 38:94-96.

33. Soeldner, J. S., and D. Sloane. 1965. Critical variables in the radioimmunoassay of serum insulin using the double antibody technic. Diabetes. 14:771779.

34. Labarca, C., and K. Paigen. 1980. A simple, rapid, and sensitive DNA assay procedure. Anal. Biochem. 102:344-352.

35. Kamps, M. P., and B. M. Sefton. 1988. Identification of multiple novel polypeptide substrates of the $v$-src, $v$-yes, $v$-fps, v-ros, and $v$-erb-B oncogenic protein tyrosine kinases utilizing antisera against phosphotyrosine. Oncogene. 2:305-315

36. Bradford, M. M. 1976. A rapid and sensitive method for quantification of of microgram quantities of protein. Anal. Biochem. 72:248-257.

37. Wilden, P. A., J. M. Backer, C. R. Kahn, D. A. Cahill, G. J. Schroeder, and M. F. White. 1990. The insulin receptor with phenylalanine replacing tyrosine1146 provides evidence for separate signals regulating cellular metabolism and growth. J. Biol. Chem. 87:3358-3362.

38. Usui, H., M. Imazu, K. Maeta, H. Tsukamoto, K. Azuma, and M. Takeda. 1988. Three distinct forms of type 2A protein phosphatase in human erythrocyte cytosol. J. Biol. Chem. 263:3752-3761.

39. Saad, M. J. A., E. Araki, M. Miralpeix, M. F. White, and C. R. Kahn. Regulation of insulin receptor substrate-1 in liver and muscle of animal models of insulin resistance. 1992. J. Clin. Invest. 90:1839-1849.

40. Friedenberg, G. R., H. H. Klein, R. Cordera, and J. M. Olefsky. 1985. Insulin receptor kinase activity in rat liver: regulation by fasting and high carbohydrate feeding. J. Biol. Chem. 260:12444-12453.

41. Karasik, A., and C. R. Kahn. 1988. Dexamethasone-induced changes in phosphorylation of the insulin and epidermal growth factor receptors and their substrates in intact rat hepatocytes. Endocrinology. 123:2214-2222.

42. Pang, D. T., B. R. Shama, J. A. Shafer, M. F. White, and C. R. Kahn. 1985. Predominance of tyrosine phosphorylation of insulin receptors during the initial response of intact cells to insulin. J. Biol. Chem. 260:7131-7136.

43. Brillon, D. J., G. R. Freidenberg, R. R. Henry, and J. M. Olefsky. 1989. Mechanism of defective insulin-receptor kinase activity in NIDDM. Diabetes. 38:397-403.

44. Takayama, S., M. F. White, V. Lauris, and C. R. Kahn. 1984. Phorbol esters modulate insulin receptor phosphorylation and insulin action in cultured hepatoma cells. Proc. Natl. Acad. Sci. USA. 81:7797-7801.

45. Gavin, J. R. III, J. Roth, D. M. Neville, P. De Meyts, and D. N. Buell. 1974. Insulin-dependent regulation of insulin receptor concentrations: a direct demonstration in cell culture. Proc. Natl. Acad. Sci. USA. 71:84-88.

46. Salhanick, A. I., M. N. Krupp, and J. M. Amatruda. 1983. Dexamethasone induces insulin receptor synthesis in cultured rat hepatocytes. J. Biol. Chem. 258:14130-14135.

47. White, M. F., J. N. Livingston, J. M. Backer, V. Lauris, T. J. Dull, A Ullrich, and C. R. Kahn. 1988. Mutation of the insulin receptor at tyrosine 960 inhibits signal transmission but does not affect its tyrosine kinase activity. Cell. 54:641-649.

48. Backer, J. M., G. G. Schroeder, C. R. Kahn, M. G. Myers Jr., P. A. Wilden, D. A. Cahill, and M. F. White. 1992. Insulin stimulation of phosphatidylinositol 3-kinase maps to insulin receptor regions required for endogenous substrate phosphorylation. J. Biol. Chem. 267:1367-1374.

49. Rice, K. M., G. E. Lienhard, and C. W. Garner. 1992. Insulin signaling through the protein phosphotyrosine pathway in 3T3-L1 adipocytes and insulin resistance. Diabetes. 41:8A. (Abstr.)

50. Bollag, G. E., R. A. Roth, J. Beaudoin, D. Mochly-Rosen, and D. E. J. Koshland. 1986. Protein kinase $C$ directly phosphorylates the insulin receptor in vitro and reduces its protein-tyrosine kinase. Proc. Natl. Acad. Sci. USA. 83:5822-5832. 